\title{
Sex differences on the feeding of the gobiid fish Bathygobius soporator in tide pools of Maiandeua Island, Pará, Brazil
}

\author{
Bruno E. Soares ${ }^{1}$, Cleonice M. C. Lobato², Danielly T. H. Freitas², \\ Roberta D. Oliveira-Raiol ${ }^{3}$ \& Luciano F. A. Montag ${ }^{2}$
}

\begin{abstract}
1. Laboratório de Ecologia de Peixes, Universidade Federal do Rio de Janeiro (UFRJ), Rio de Janeiro, Brasil. (brunoeleres@yahoo.com.br) 2. Laboratório de Ecologia e Conservação, Universidade Federal do Pará (UFPA), Belém, Brasil.

3. Universidade da Amazônia (UNAMA), Belém, Brasil.
\end{abstract}

Received 4 August 2015

Accepted 2 May 2016

DOI: $10.1590 / 1678-4766 e 2016008$

\begin{abstract}
Bathygobius soporator (Valenciennes, 1837) is one of the most common fishes in tide pools in the estuary of Pará state, and has an omnivorous feeding habit. This study examined the diet of the species in Maiandeua Island, and aimed to: (i) describe the diet of B. soporator through indexes based on the occurrence and weight of consumed items; and (ii) evaluate if there is variation in diet composition between males and females. Frequency of Occurrence, frequency of weight and Alimentary Index were calculated for each item, and differences in the diet composition of males and females were observed through multivariate analyses (ANOSIM, NMDS and SIMPER). Bathygobius soporator presented carnivorous feeding habit, eating mainly crustaceans, and differences among males and females were observed, males consuming smaller amounts of crustaceans and including algae in their diet.
\end{abstract}

KEYWORDS. Estuaries, diet, trophic guild.

RESUMO. Diferença entre sexos na alimentação do peixe gobídeo Bathygobius soporator em poças de maré da Ilha de Maiandeua, Pará, Brasil. Bathygobius soporator (Valenciennes, 1837) é um dos peixes mais comuns em poças de maré no estuário paraense e apresenta hábito alimentar onívoro. Esse estudo examinou a dieta da espécie na Ilha de Maiandeua, com o objetivo de: (i) descrever a dieta de B. soporator através de índices baseados na ocorrência e biomassa dos itens alimentares; (ii) avaliar se há variação na composição da dieta entre machos e fêmeas. Calculou-se a frequência de ocorrência, frequência de peso e o Índice de Importância Alimentar, e utilizaram-se análises multivariadas (ANOSIM, NMDS e SIMPER) para avaliar a diferença na composição da dieta de machos e fêmeas. Bathygobius soporator apresentou hábito carnívoro, consumindo predominantemente crustáceos, e houve variação na dieta de machos e fêmeas, sendo que machos consumiram crustáceos em menor quantidade e incluíram algas em sua dieta.

PALAVRAS-CHAVE. Estuário, dieta, guilda trófica.

Bathygobius soporator (Valenciennes, 1837) (Perciformes, Gobiidae) inhabits shallow coastal waters up to two meters deep and is one of the most common fishes in American Atlantic shores. Abundant in the estuarine area of Pará State (SoARES et al., 2013), the species can be found from rivers mouths and mangroves to coral reefs, has benthic habits, uses crevices in reef areas and rocky shores, and holes and the roots of mangroves as refugee (MENDES, 2006), and is common in tide pools (GARZÓN-FERREIRA \& ACERO, 1992).

Tide pools are environments formed during the low tide, where a small amount of water is retained in depressions in the intertidal zone (FANGUE et al., 2001). These pools present constant and intense variations in its physical and chemical characteristics (Metaxas \& Scheibling, 1993) and, at the Brazilian North region, these variations are more intensified due to a macro tide scheme, with tidal range that can vary from $4 \mathrm{~m}$ to $6 \mathrm{~m}$ (BARBOSA et al., 2007).

In relation to its trophic ecology, Bathygobius soporator is considered an opportunistic species due to a predation preference on highly abundant groups in its environment, and omnivorous, for consuming algae, crustaceans and fishes (Nascimento \& Peret, 1986; Lopes \& Oliveira-Silva, 1998). Despite the wide knowledge about the diet of B. soporator in Southern Brazil and the importance of sexual morphologic and behavioural dimorphism in feeding ecology (SCHARNWEBER et al., 2011; McGeE \& WAINWRIGHT, 2013), there is no information about sexual differences in the diet composition of the species.

The diet of Bathygobius soporator has not been studied in the North region of Brazil, which provides a different circumstance due to macro tide regime and the gradient of exposure time that the tide pools present during 
the low tide. Considering the importance of feeding studies to understand interspecific relationships and for proper management measures and preservation production (ESTEVES \& ArANHA, 1999), this study examined individuals from different tide pools in Maiandeua Island, PA and aimed to: (i) describe the diet B. soporator through indexes based on the occurrence and relative weight of consumed items; (ii) evaluate whether there is variation in diet composition between males and females of $B$. soporator.

\section{MATERIAL AND METHODS}

Study Area. The Maiandeua Island (00³5'0" $00^{\circ} 38^{\prime} 29^{\prime \prime} \mathrm{S}, 47^{\circ} 31^{\prime} 54^{\prime \prime}-47^{\circ} 34^{\prime} 57^{\prime \prime} \mathrm{W}$ ), in the municipality of Maracanã, the north-eastern of Pará state, is one of the mouths of the Pará estuary, receiving the waters of the Maracanã and Marapanim rivers. It has 2.378 ha in length, having been transformed into an APA ("Área de Proteção Ambiental" or Environmental Protection Area) under state law n ${ }^{\circ} 5.621 / 90$.

The area is marked by two hydrological periods throughout the year, a rainy period from December to May, and a dry period from June to November; presenting hot and humid climate, with strong macrotidal influence (BARBOSA et. al., 2007). The intertidal zone of Maiandeua island is characterized by extensive rock shore areas, which contains tide pools of different sizes.

Sampling and data analysis. Samples were collected between April and November 2008 in Maiandeua Island, and consisted of scanning the tide pools searching and catching target species with a sieve with a $5 \mathrm{~mm}$ mesh. The sampling was performed at low tide for three hours (an hour and a half before the peak of low tide, and an hour and a half after the peak of low tide), and each pool was sampled to its depletion. Samples were collected in accordance with the authorization provided by SEMA under the registration number $02 / 2010$. Individuals were fixed in $10 \%$ formalin and stored in $70 \%$ alcohol.

In the laboratory, the specimens were measured to standard length (SL) using a digital caliper with $150 \mathrm{~mm}$ and precision of $0.1 \mathrm{~mm}$, and the total weight (TW) using a digital scale with $200 \mathrm{~g}$ capacity and $0.1 \mathrm{~g}$ accuracy. The sex of the individuals was determined by macroscopic observation of the gonads and genital papillae according TAVOLGA (1954). The subjects were open for the withdrawal of the digestive tract, which were stored in $70 \%$ alcohol until analysis under a stereomicroscope and identification of food items required to taxonomic classification. The weight of food items was taken using balance with a $20 \mathrm{~g}$ capacity and accuracy of $0.001 \mathrm{~g}$.

Food items were submitted to the following qualiquantitative analysis: i) Frequency of Occurrence (FOi\%); ii) gravimetric frequency $(\mathrm{P} \%)$; and iii) food importance (IA \%) of each food category. The Frequency of Occurrence is calculated by dividing the number of stomachs where a particular item was identified by the number of stomachs containing food analyzed (HysLOP, 1980). The gravimetric frequency is obtained from the ratio of the total weight of each food item on the sum weight of all food items (HYNES, 1950). The Alimentary Index (KaWAKAmI \& VAzzoler, 1980) considers the Frequency of Occurrence (FOi\%) and weight frequency $(\mathrm{P} \%)$ and can be obtained by $I A i^{=}$ $\left(\mathrm{FOi}^{*} \mathrm{P}\right) / \sum(\mathrm{FOi} * \mathrm{P})$, where: $I A i=$ food importance index; $i=$ $1,2, \ldots \mathrm{n}=$ particular food item; $F O i=$ food item frequency $i$, and $P=$ weight $(\mathrm{g})$ of food item $i$.

The Similarity Analysis (ANOSIM) was used to identify differences in the intake of food items between males and females of Bathygobius soporator using the relative biomass of consumed items by each individual. Dissimilarities between individuals were observed in a Non-Metric Multidimensional Scaling (NMDS), using the coefficient of Bray-Curtis, and later an Analysis of Similarity Percentage (SIMPER) was used to observe which items were responsible for the variation between the sexes. The ANOSIM was conducted at 5\% level of significance and all tests were performed in the PRIMER 6.0 program.

\section{RESULTS}

A total of 72 individuals were analyzed, 22 (30.55\%) males and $48(66.67 \%)$ females, and two individuals did not have their sex determined $(2.78 \%)$. The standard length (SL) of the specimens ranged from $1.2 \mathrm{~cm}$ to $9.37 \mathrm{~cm}( \pm 6.88$ $\mathrm{cm} \pm 1.23 \mathrm{~cm}$ ) and total weight (TW) ranged from $0.86 \mathrm{~g}$ to $23.80 \mathrm{~g}( \pm 9.67 \mathrm{~g} \pm 4.25 \mathrm{~g})$. Only seven individuals $(10 \%$ of the sample) presented an empty digestive tract. Among subjects with food in the digestive tract, seven specimens presented sand particles with the food content (10\%) and 42 specimens $(65 \%)$ had digested organic matter.

We identified eight food items for Bathygobius soporator (Tab. I), wherein the crustacean Petrolisthes armatus (Gibbes, 1850) was the most abundant prey in the species diet, being consumed by more than $60 \%$ of individuals and composing about $90 \%$ the total biomass ingested by analyzed individuals. The second most important item, material of higher plants, showed only $2 \%$ of food importance, highlighting the high relative importance of $P$. armatus for the target species.

There was variation in male and female diet compositions $(\mathrm{R}=0.36 ; \mathrm{p}=0.002)$ and the formation of three main groups of predators were observed: Group 1 was composed mostly of females and fed up predominantly of crustacean P. armatus; Group 2 consisted of three males who have intermediate consumption $P$. armatus and high volume of algae in their digestive tract; while Group 3 consumed predominantly higher plant material, but in small quantities (Fig. 1).

The average similarity between females (74.07) was higher than in males (25.42), showing that males have broader diet than females, using non-consumed (e.g. algae) or shortly consumed (e.g. plant material) items. Males and females show average dissimilarity of 63.6, and the difference in their diets was caused by a greater consumption of $P$. armatus by 
Tab. I. Frequency of Occurrence (FOi), gravimetric frequency (FP) and Alimentary Index (IAi) of food items consumed by Bathygobius soporator (Valenciennes, 1837) in Maiandeua Island, Pará, Brazil.

\begin{tabular}{|c|c|c|c|}
\hline Food Item & $\mathrm{FOi}$ & $F P$ & $I A i$ \\
\hline \multicolumn{4}{|l|}{ Vegetal Source } \\
\hline Algae: Rhodophyta & 0.046154 & 0.040845 & 0.003089 \\
\hline Higher plants materials & 0.276923 & 0.045192 & 0.020506 \\
\hline \multicolumn{4}{|l|}{ Animal Source } \\
\hline Rotifera & 0.015385 & $<0.001$ & $<0.001$ \\
\hline Isopoda & 0.092308 & 0.000112 & $<0.001$ \\
\hline Crustacea eggs & 0.107692 & 0.000131 & $<0.001$ \\
\hline Crustacea fragments & 0.046154 & 0.008825 & 0.000667 \\
\hline Crustacea: Petrolisthes armatus & 0.661538 & 0.900004 & 0.975574 \\
\hline Teleostei: Mugil sp. & 0.015385 & 0.004871 & 0.000123 \\
\hline
\end{tabular}

females and increased consumption of plant material and algae by males (Tab. II).

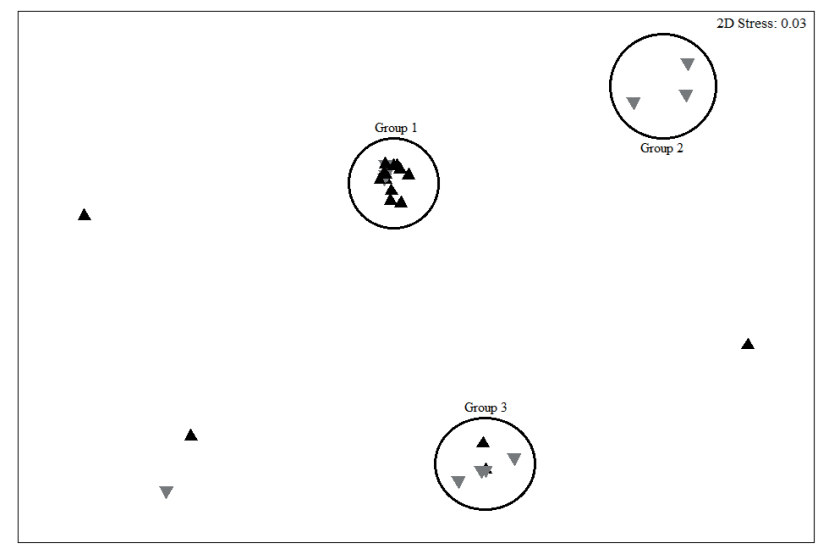

Fig. 1. Non-Metric Multidimensional Scaling (NMDS) shows the variation in the diet of males and females Bathygobius soporator (Valenciennes, 1837) specimens and the formation of three main groups with different diets in the population of Maiandeua Island, Pará, Brazil.

Tab. II. Similarity Percentage analysis (SIMPER), showing the average volume consumed by females and males of Bathygobius soporator (Valenciennes, 1837) and the percentage contribution of each item to the dissimilarity between the sexes in Maiandeua Island, Pará, Brazil.

\begin{tabular}{lccc}
\hline \multirow{2}{*}{ Food items } & \multicolumn{2}{c}{ Average Volume } & Contribution \\
& Females & Males & $(\%)$ \\
\hline Algae & 0.00 & 0.20 & 83.15 \\
Plant material & 0.07 & 0.34 & 68.5 \\
Petrolisthes armatus & 0.87 & 0.40 & 42.16 \\
Crustacea fragments & 0.02 & 0.07 & 90.33 \\
\hline
\end{tabular}

\section{DISCUSSION}

The gobiid Bathygobius soporator that inhabits tide pools in Maiandeua Island presented omnivorous feeding habit, using both animal (e.g. crustaceans, fish) and vegetal (e.g. algae, higher plant material fragments) items. The main item in the diet of the species was the crustacean Petrolisthes armatus, but females and males showed different diets, where males consumed smaller amounts of crustaceans and more items of vegetal origin.
The low number of empty and completely filled digestive tracts, together with a large percentage of stomachs with little amounts of food and a high percentage of Digested Organic Matter, indicates a feeding rate almost sequential, with a constant foraging throughout the day. According to HAHN et al. (1999), many fish populations present sequential foraging habit or present a prolonged period of daily activity. This result is similar to that found in Itaparica Island, Bahia State, Brazil, where Lopes \& OliveIrA-Silva (1998) showed low frequency of empty stomachs and high rate of organic matter digested in this specie diet.

Crustaceans are preferred items for a large part of demersal fishes in estuarine and intertidal regions (KRUMME $e t$ al., 2007; Chaves \& Vendel, 2008). Lopes \& OliveIRA-Silva (1998) showed, for example, that Bathygobius soporator predominantly consumed crustaceans of the infraorder Brachyura in Itaparica Island. Besides the benthic habit, suitable for prey crustaceans on the substrate, in Maiandeua Island the high consumption of $P$. armatus is accompanied by the high abundance of these crustaceans in the tidal pools where the specimens were collected, especially when compared to colder regions of Brazil (OLIVEIRA et al., 2013).

About $10 \%$ of the individuals showed sand particles with the food contents. However, this does not happen due to an iliophagous habit, since the species' digestive tract is not long and intensely coiled, which is one of the necessary adaptations for this type of feeding (MORAEs et al., 1997; Fugi \& HAHN, 1991). The occurrence of sand with food items Bathygobius soporator must occurs because of the main predatory tactics of the species, the speculation of the substrate, characterized by the search of prey near the pool bottom and assault on the substrate to capture it (M. Nomura, unpubl. data), suggesting accidental ingestion.

Algae were infrequent in the species diet, but showed high importance for the biomass percentage and occurred only in the diet of males; higher plants fragments were consumed by males and females, but in greater quantity by males. Higher plant fragments occurs in the diet of several populations of this species (NASCIMENTO \& PeRET, 1986; LoPES, 1989; LoPeS \& OliveIRA-SiLVA, 1998), being one of the main factors to consider Bathygobius soporator as an omnivorous species by some authors. However, M. Nomura (unpubl. data) studied 
the behavior of $B$. soporator in the São Sebastião coast (São Paulo, Brazil) and did not recorded direct predation on macroalgae banks, indicating incidental ingestion. Thus, since males and females consume higher plant fragments, even if in small amounts, future investigations should be done to evaluate the role of vegetal source items on the diet populations of $B$. soporator.

The sexual-based differences in the diet composition of Bathygobius soporator herein reported are mainly structured by a higher degree of consumption of Petrolisthes armatus by females than by males, and in the inclusion of algae in the diet of males. The uncertainty that $B$. soporator uses algae as trophic resources is still to be tested, but TAVOLGA (1956) described the pre-reproductive behavior of the species and showed that males clean the nest area through ingestion of algae and other debris, which may be a factor in the occurrence of macroalgae in B. soporator males. Furthermore, the lower ingestion of crustaceans by males and high feeding dissimilarity between them is a product of the ingestion of macroalgae, which highlights the importance of behaviour in sex-based differences in diet composition and trophic structure.

According to this study, Bathygobius soporator presents carnivorous feeding habits prone to carcinofagia and incidental consumption of plant food items in Maiandeua Island. In addition, the diet was mainly composed of Petrolisthes armatus, an abundant porcellanid crustacean in tide pools that highlight the opportunistic feeding aspect of this species, with differences between the diet of males and female, where males had broader and more diverse diet than females by the consumption of macroalgae.

Acknowledgements. The authors are thankful for the financial support to PIBIC/UFPA (115361/2009-0) and to Secretaria do Meio Ambiente for allowing the sampling. We are also thankful for the oceanographer Edmir A. Celestino for conducting the data collection.

\section{REFERENCES}

Barbosa, V. M.; Gregório, A. M. S.; Busman, D. V.; Costa, R. A. A. M.; Souza-Filho, P. W. M. \& Pereira, L. C. C. 2007. Estudo morfodinâmico durante uma maré equinocial de sizígia em uma praia de Macromaré do litoral amazônico (Praia de Ajuruteua-PA, Brasil). Boletim Paranaense de Geociências 60-61:31-43.

Chaves, P. T. \& Vendel, A. L. 2008. Análise comparativa da alimentação de peixes (Teleostei) entre ambientes de marisma e de manguezal num estuário do sul do Brasil (Baía de Guaratuba, Paraná). Revista Brasileira de Zoologia 25:10-15.

Esteves, K. E. \& Aranha, J. M. R. 1999. Ecologia Trófica de Peixes de Riachos. Oecologia Brasiliensis 6:157-182.

Fangue, N. A.; Flaherty, K. E.; Runner, J. L.; Cole, G.; Hansen, K. S.; Hinote, R.; Noel, B. L.; Wallman, H. \& Bennett, W. A. 2001. Temperature and hypoxia tolerance of selected fishes from a hyperthermal rockpool in the Dry Tortugas, with notes on diversity and behavior. Caribbean Journal of Science 37:81-87.
FUGI, R. \& HAHN, N. S. 1991. Espectro alimentar e relações morfológicas com o aparelho digestivo de três espécies comedoras de fundo do rio Paraná, Brasil. Revista Brasileira de Biologia 51:873-879.

Garzón-Ferreira, J. \& Acero, A. P. 1992. Los Peces del Genero Bathygobius (Perciformes: Gobiidae) del Caribe Colombiano. Anales del Instituto de Investigaciones Marinas de Punta de Betin 21:23-32.

Hahn, N. S.; Loureiro, V. E. \& Delariva, R. L. 1999. Atividade alimentar de curvina Plagioscion squamosissimus (Heckel, 1840) (Perciformes, Sciaenidae) no rio Paraná. Acta Scientiarum 21:309-314.

Hynes, H. B. N. 1950. The food of fresh water sticklebaks (Gasterosteus aculeatus and Pygosteus pungititus), with a review of methods used in studies of the fishes. Journal of Animal Ecology 19:36-58.

HysLop, E. J. 1980. Stomach contents analysis; a review of methods and their application. Journal of Fish Biology 17:411-429.

KaWaKami, E. \& Vazzoler, E. 1980. Método gráfico e estimativa de índice alimentar aplicado no estudo de alimentação de peixes. Boletim do Instituto Oceanográfico 29:205-207.

Krumme, U.; Keuthen, H.; Saint-Paul, U. \& Villwock, W. 2007. Contribution to the feeding ecology of the banded puffer fish Colomesus psittacus (Tetraodontidae) in north Brazilian mangrove creeks. Brazilian Journal of Biology 67:383-392.

LOPES, P. R. D. 1989. Nota prévia sobre a alimentação de Bathygobius soporator (Valenciennes, 1837) (Pisces, Gobiidae) na Praia da Guanabara, Baía de Guanabara (RJ). Revista Unimar 11:75-81.

Lopes, P. R. D. \& OliveIRA-Silva, J. T. 1998. Alimentação de Bathygobius soporator (Valenciennes, 1837) (Actinopterygii: Teleostei: Gobiidae) na localidade de Cacha Pregos (Ilha de Itapatica), Bahia, Brasil. Biotemas 11:81-92.

McGee, M. D. \& Wainwright, P. C. 2013. Sexual dimorphism in the feeding mechanism of threespine stickleback. The Journal of Experimental Biology 216:835-840.

Mendes, L. F. 2006. História natural dos amborés e peixes-macaco (Actinopterygii, Blennioidei, Gobioidei) do Parque Nacional Marinho do Arquipélago de Fernando de Noronha, sob um enfoque comportamental. Revista Brasileira de Zoologia 23:817-823.

Metaxas, A. \& Scheibling, R. E. 1993. Community structure and organization o tidepools. Marine Ecology Progress Series 98:187-198.

Moraes, M. F. G. P.; Barbola, I. F. \& Guedes, E. A. G. 1997. Alimentações e relações morfológicas com o aparelho digestivo do "Curimbatá", Prochilodus lineatus (Valenciennes) (Ostheichthyes, Prochilodontidae), de uma lagoa do Sul do Brasil. Revista Brasileira de Zoologia 14:169180.

Nascimento, M. T. \& Peret, A. C. 1986. Reprodução e Nutrição de Bathygobius soporator (Cuvier \& Valenciennes, 1837) do Canal do Itajuru, Cabo Frio - RJ (Perciformes - Gobioidei - Gobiidae). Ciência e Cultura 38:1404-1413.

Oliveira, D. B.; Silva, D. C. \& Matinelli-Lemos, J. M. 2013. Larval and adult density of the porcellanid crab Petrolisthes armatus (Anomura: Porcellanidae) in an Amazon estuary, northern Brazil. Zoologia 30:592600.

Scharnweber, K.; Plath, M. \& Tobler, M. 2011. Trophic niche segregation between the sexes in two species of livebearing fishes (Poecilidae). Bulletin of Fish Biology 13:11-20.

SoARES, B. E.; RufFeIL, T. O. B. \& MontAG, L. F. A. 2013. Ecomorphological patterns of the fishes inhabiting the tide pools of the Amazonian Coastal Zone, Brazil. Neotropical Ichthyology 11:845-858.

TAvoLGA, W. N. 1954. Reproductive behavior in the gobiid fish Bathygobius soporator. Bulletin of the American Museum of Natural History 104:427-460.

1956. Pre-spawning behavior in the gobiid fish, Bathygobius soporator. Behaviour 9:53-74. 